\title{
Electrochemical Degradation of Benzoquinone in a Flow through Cell with Carbon Fibers
}

\author{
Jang-Hee Yoon, ${ }^{\dagger-}$ JeeEun Yang, Yoon-Bo Shim,,$^{\dagger{ }^{\star}}$ and Mi-Sook Won ${ }^{-*^{*}}$ \\ -Department of Chemistry Pusan National Lnwersity, Busan 609-735, Korea. "E-mail vbshimapusan.ac.kr \\ -Busan Center, Korea Basic Science Institute, Busan 609-735, Korea. "E-mail: mswonakbsi.re.kr \\ Received December 6, 2006
}

\begin{abstract}
The anodic degradation of benzoquinone(BQ). a model compound for wastewater treatment was carried out using a home-made flow-through electrochemical cell with carbon fibers. To optimize the controlled current electrolysis condition of an aqueous BQ solution, the experimental variables affecting the degradation of $\mathrm{BQ}$. such as the applying current. $\mathrm{pH}$. reaction time. and flow rate of the $\mathrm{BQ}$ solution were examined. The degradation products of the oxidation reaction were identified by High Performance Liquid Chromatography and Inductively Coupled Plasma Atomic Emission Spectrometer. Low molecular weight aliphatic acids. and $\mathrm{CO}_{2}$ were the major products in this experiment. The removal efficiency of $\mathrm{BQ}$ from the solution increased with the applying current and time. $99.23 \%$ of $1.0 \times 10^{-2} \mathrm{MBQ}$ was degraded to aliphatic acids and $\mathrm{CO}_{2}$ when the applying current is $175 \mathrm{~mA}$ in a 12 hr electroly'sis
\end{abstract}

Key Words : Degradation of benzoquinone, Flow-through electrochenical cell, Carbon fibers electrode

\section{Introduction}

The treatment of organic compounds as contaminants in wastewater is a subject of great interests. due to the ecological and health care issues. The industrial wastewater contains organic pollutants. especially: aromatic hydrocarbons that can be either toxic or resistant to the most aquatic microorganisms and mammals.' For example. aromatic amines. such as aniline and m-nitrosoaniline can react readily to convert hemoglobin to methamoglobin in the blood. thereby preventing the uptake of oxygen. These aromatic amines are commonly produced as by-products in the petroleum. paper. coal and chemical industries." Beside of this. phenols are found in the wastewater of the most processes that involve aromatic organic chemicals. The common contamination sources are pulp. paper mills. petrochemical refineries herbicide. some plastics and glue manufacturing. and coke plants. ${ }^{3 . t}$ Many papers have reported on the treatment of these aromatic hydrocarbons contained in industrial and residential wastewater that are resistant to biological. ozone treatment and other chemical method. ${ }^{5-\delta}$ Some studies have focused on determining the chemical or electrochemical oxidation conditions required to reach one of the following objectives: (a) to modify the chemical structure of an organic molecule making it more biodegradable: (b) to partially destroy the molecule to decrease its toxicity: (c) to completely oxidize the molecule to $\mathrm{CO}_{\text {. }}$ or other inorganic products. . $^{-i l}$

Electrochemical oxidation is currently accepted as the oxidative treatment of certain organic compounds ${ }^{12}$ and has been utilized in the treatment of effluent streams in such a way that their Chemical Oxyen Demand (COD) was reduced or industrial toxic species were destroyed. ${ }^{13-15}$ For the electrochemical treatment of phenols in water the anodic oxidation of phenols with $\mathrm{Ti} / \mathrm{SnO}_{2}$ or $\mathrm{Ti} / \mathrm{IrO}$ s electrodes have been carried out in the presence of $\mathrm{NaCl} \cdot{ }^{16}$ which cataly ze an oxidation reaction by the participation of electrogenerated $\mathrm{ClO}_{4}^{-}$and it has been applied to wastewater treatment via the use of $\mathrm{PbO}_{2}$ packed bed anodes. ${ }^{17}$ In addition, the various anode materials such as noble-metal oxides and antimony-doped tin oxides have been employed for the oxidation of benzoquinone (BQ) and maleic acid at a high anodic potential. The efficiency of BQ oxidation was found to be depended on the properties of the anode materials. ${ }^{18}$ Thus. the use of adequate anode materials for electrolysis is essential. because the efficiencies of degradation of organic materials depend on the nature of such materials. The most commonly used anode materials for the electrochemical treatment of organic pollutants are metal oxides such as. lead. modified lead oxide. ${ }^{19}$ tin. and/or antimony because of economical requirements and the adsorption of products to the electrode surface are minimized. However, these materials would not be acceptable for wastewater treatment due to their inherent toxicity. the limited lifetime and the price of anode materials. ${ }^{\prime}$ The problem of mass-transfer limitations of a very dilute reactant can be solved by the use of an extended-surface and packed electrode." Moreover. the anode materials showing a high current efficiency should be used for electrochemical treatments

In the present study. a flow-through electrochemical cell (FTEC) packed with carbon fibers. was used to electrolyze $\mathrm{BQ}$ and optimize the parameters for its electrolysis. which is more stable than phenol. "2 Such electrodes are not only promoting for high mass-transfer rates. but also providing high surface areas within a compact volume without further contamination. However, it requires the separation between the electrolyte and the degradation solutions to achieve both high mass-transfer rate and high surface areas. Thus we designed the FTEC for the efficient treatment of $\mathrm{BQ}$. The experimental parameters to affect the degradation efficiency 
were optimized the applied input current. $\mathrm{pH}$, reaction tine. and flow rate. After the electrolysis of $\mathrm{BQ}$. Inductively Coupled Plasma Atomic Emission Spectrometer (ICP-AES) and High Perfomance Liquid Chromatography (HPLC) were used to analyze the degradation products

\section{Experimental}

Fresh a $1.0 \times 10^{-2} \mathrm{M}$ of $\mathrm{BQ}$ (Aldrich. USA) solution was purified by sublimation. A $0.5 \mathrm{M}$ sulfuric acid solution (MERCK. Germany) was used for electrolyte. For the working electrode, the carbon fibers (TOHO Rayon. Japan)were used after pre-treated in $6.0 \mathrm{M}$ hydrochloric acid for $2 \mathrm{hr}$ at $80^{\circ} \mathrm{C}$. rinsed with deionized water. and dried at $105^{\circ} \mathrm{C}$ in an oven. A Vyco porous glass tube (pore size $4.0 \mathrm{~mm}$. Corning. USA) was pre-treated in $1.2 \mathrm{M}$ hyddrochloric acid for $1 \mathrm{hr}$ at 80 and rinsed with deionized water. For the adsorption of carbon dioxide. $5.0 \times 10^{-2} \mathrm{M} \mathrm{Ba}(\mathrm{OH})$ ( (Aldrich. USA) was used. Standard materials for HPLC. oxalic acid succinic acid. maleic acid and hydroquinone were purchased from Supelco Co. (USA). All aqueous solution were prepared with purified distilled water [Milli-Q system $(18 \mathrm{M} \Omega \cdot \mathrm{cm})$ ].

The electrochemical decomposition of $\mathrm{BQ}$ was conducted by a Potentiostat/Galvanostat (Model KST-P1. Kosentech Co. South Korea) using a home-made FTEC system. A peristaltic pump (Perkin Elmer. USA) was used to carry out the reactant solution. For a large electro-active surface area

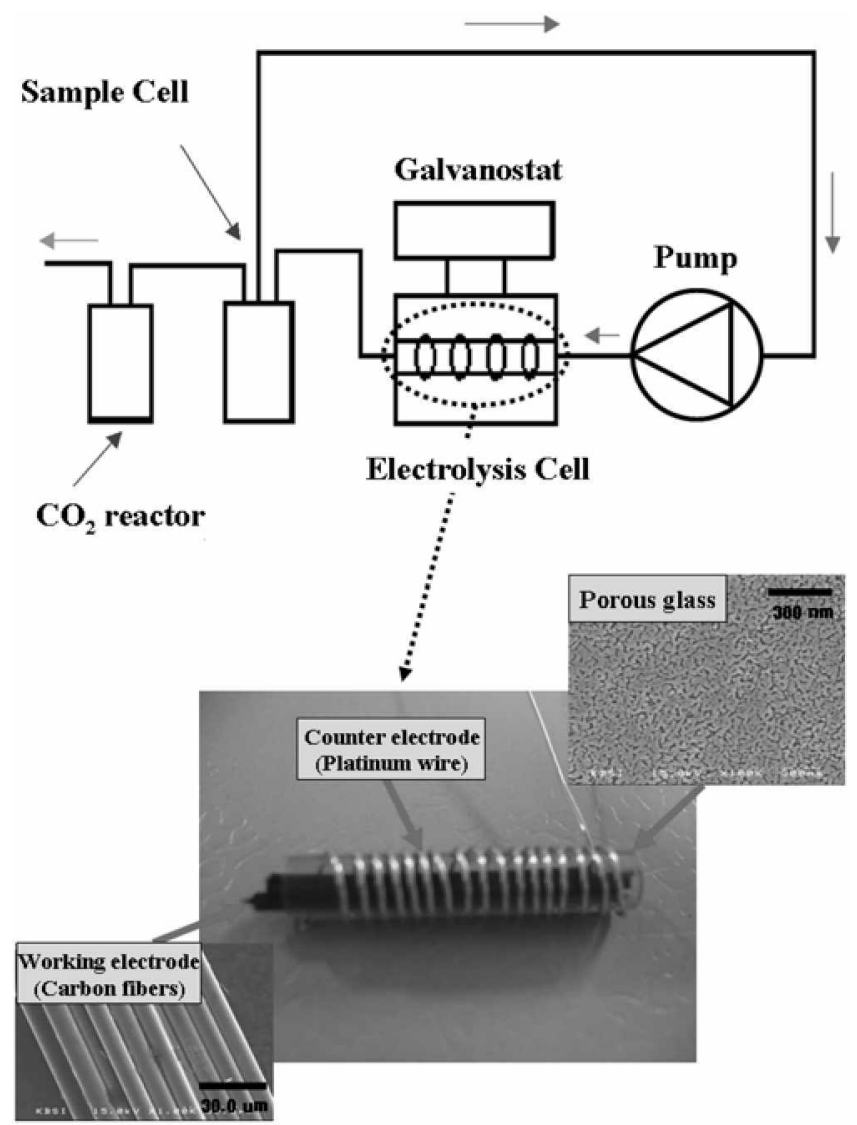

Figure 1. Flow-through electrochenical cell designed for controlled current electrolysis of aqueous solution of $\mathrm{BQ}$. per unit volume. a porous glass tube and carbon fibers was used to assemble a flow through cell. Figure 1 shows a detailed description of the FTEC used for the electrolysis of a $\mathrm{BQ}$ solution. ${ }^{23}$ The similar type of flow cell was described previously ${ }^{-4}$ Chromatographic analysis of the degradation products were carried out using an HPLC (Waters. Alliance. USA) with a C.18 column at $25^{\circ} \mathrm{C}$ and the UV detector was set at $210 \mathrm{~nm}$. A $5.0 \times 10^{-\hat{2}} \mathrm{M}$ of potassium phosphate monobasic solution was used as a mobile phase. The concentration of $\mathrm{Ba}^{-}$ion was determined by ICP-AES (IRIS. Thermo Jarrell Ash. USA) with a CID detector at an emission line of $233.527 \mathrm{~nm}$.

A $1.0 \times 10^{-2} \mathrm{M}$ of $\mathrm{BQ}$ solution was prepared by dissolving $\mathrm{BQ}$ in $0.5 \mathrm{M} \mathrm{H}_{2} \mathrm{SO}_{4}$. The current was applied to the electrolytic cell shown in Figure 1. A separate exit was installed in the FTEC (Figure 1) to collect $\mathrm{CO}_{2}$ that was bubbled through a basic solution of $0.05 \mathrm{M}$ barium hydroxide during the electrolysis.. ${ }^{\prime}$ The efficiency of degradation was determined from the amount of $\mathrm{CO}$. generated. which was calculated stoichiometrically from the concentration of residual $\mathrm{Ba}^{2+}$ was determined by the ICP. AES. HPLC was used for the analysis of degraded intermediates and final products during the anodic oxidation process. The compounds were identified by comparing chromatogranıs of standards.

\section{Results and Discussion}

Cyclic voltammetric behaviors of BQ. Figure 2 shows recorded $\mathrm{CVs}$ for the carbon fiber electrode in a flow cell from $+0.7 \mathrm{~V}$ to $-0.8 \mathrm{~V} v \mathrm{~s}$. $\mathrm{Ag} / \mathrm{AgCl}$ at a scan rate of $50 \mathrm{mV} /$ sec in (a) a $5 \times 10^{-2} \mathrm{M}$ of $\mathrm{KCl}$ solution and (b) a $1.0 \times 10^{-2}$ $\mathrm{M} B Q$ solution containing $5 \times 10^{-2} \mathrm{M}$ of $\mathrm{KCl}$ solution, separately: The working electrode was carbon fibers. Platinum wire was used as a counter electrode and Ag/AgCl sat'd KCl was used as a reference electrode. As shown in Figure 2(b). a pair of redox peaks was observed at $+0.05 \mathrm{~V} /-0.24 \mathrm{~V} w \mathrm{Ag} /$ $\mathrm{AgCl}$. which corresponds to the two-electron redox reaction

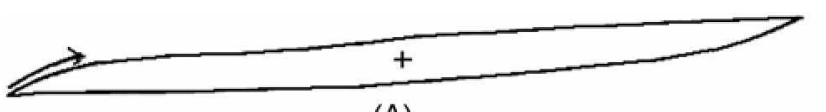

(A)

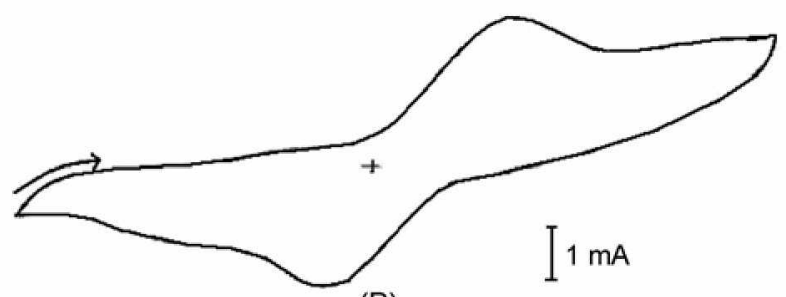

(B)

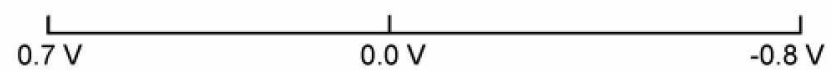

Figure 2. Cyclic voltammograms recorded in (a) $5.0 \times 10^{-2} \mathrm{M} \mathrm{KCl}$, and (b) $1.0 \times 10^{-2} \mathrm{M} \mathrm{BQ}$ aqueous solution with $5.0 \times 10^{-2} \mathrm{M} \mathrm{KCl}$ using the carbon fibers electrode in the FTEC. Scarn rate: $50 \mathrm{~m} \mathrm{Vs}^{-1}$. 


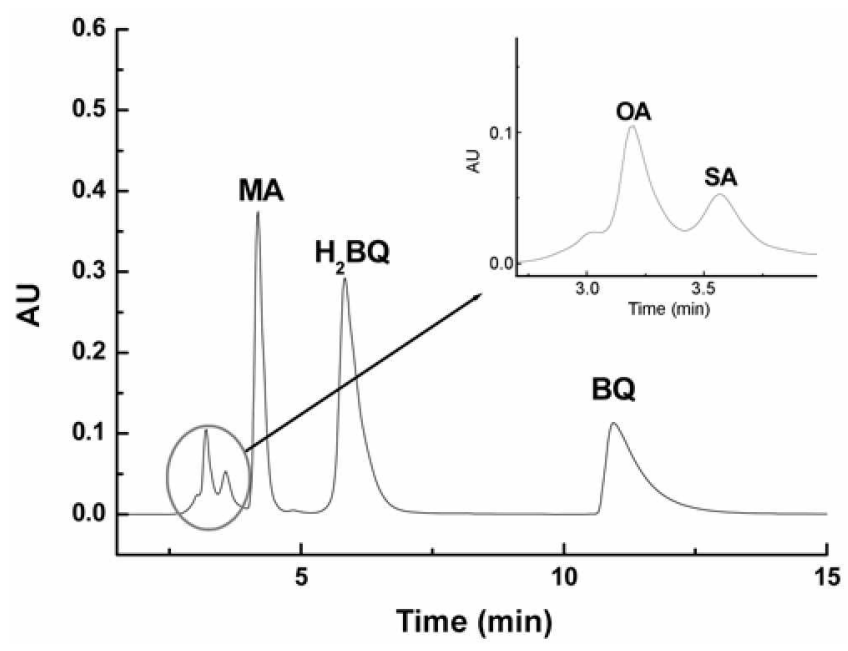

Figure 3. A chromatogram obtained for $25 \mathrm{~mL}$ of the degraded products of a $1.0 \times 10^{-\frac{1}{-}} \mathrm{M}$ aqueous solution of $\mathrm{BQ}$ electrolvzed at $100 \mathrm{~mA}$ for $5 \mathrm{hr}$.

of $\mathrm{BQ}$ in an acidic solution as previously described ${ }^{25}$;

$$
B Q(\alpha q)+2 H^{\top}+2 e^{-} \leftrightarrow H_{2} B Q(\alpha q)
$$

The constant current electrolysis of $\mathrm{BQ}$. Galvanostatic electrolysis of $\mathrm{BQ}$ in aqueous solutions were performed with the home-made FTEC. The experimental variables for the electrochemical treatments of a $\mathrm{BQ}$ solution were optimized. A typical HPLC chromatogram obtained for the degradation products after the electrolysis of a $1.0 \times 10^{-3}$ $M B Q$ solution is shown in Figure 3. Five peaks with different retention times were revealed for the electrochemically treated $\mathrm{BQ}$ solution. The products identified by the authentic samples were oxalic acid $\left(\mathrm{t}_{R}=3.19 \mathrm{~min}\right)$, succinic acid $\left(t_{R}=3.57 \mathrm{~min}\right)$. maleic acid $\left(t_{R}=5.85 \mathrm{~min}\right)$. hydroquinone $\left(\mathrm{t}_{R}=5.998 \mathrm{~min}\right)$, and untreated $\mathrm{BQ}\left(\mathrm{t}_{R}=\right.$ $10.95 \mathrm{~min}$ ). The retention time of each product was confirmed using the standard aliphatic acid at same analyses conditions. In addition to these compounds. the chromatograms also showed very small peaks related to minor oxidation products, which were not identified. However. they may be the aliphatic acids because their retention times are very close to those of the identified acids. ${ }^{36}$ The final product of the electrolytic degradation of $\mathrm{BQ}$ was $\mathrm{CO}_{2}$. which was confirmed by the production of $\mathrm{BaCO}_{3}$ by precipitating from the produced $\mathrm{CO}_{2}$ and a $\mathrm{Ba}(\mathrm{OH})=$ solution.

Effect of applied current density and time on the degradation of BQ. The effect of the applied current on the degradation of $\mathrm{BQ}$ was studied. The plot of the applied current 1 s. peak area is shown in Figure 4. Galvanostatic electrolyses for $25 \mathrm{~mL}$ of $1.0 \times 10^{-1} \mathrm{M}$ BQ aqueous solutions were carried out in a FTEC at a flow rate of 1.6 $\mathrm{mL} / \mathrm{min}$. The $\mathrm{BQ}$ solution was recycled through the FTEC and a reservoir bottle. Figure 4 shows the peak areas corresponding to the residual reactant and degradation products in solution as the function of applied current after the oxidation of $\mathrm{BQ}$ for an hour at the different applied

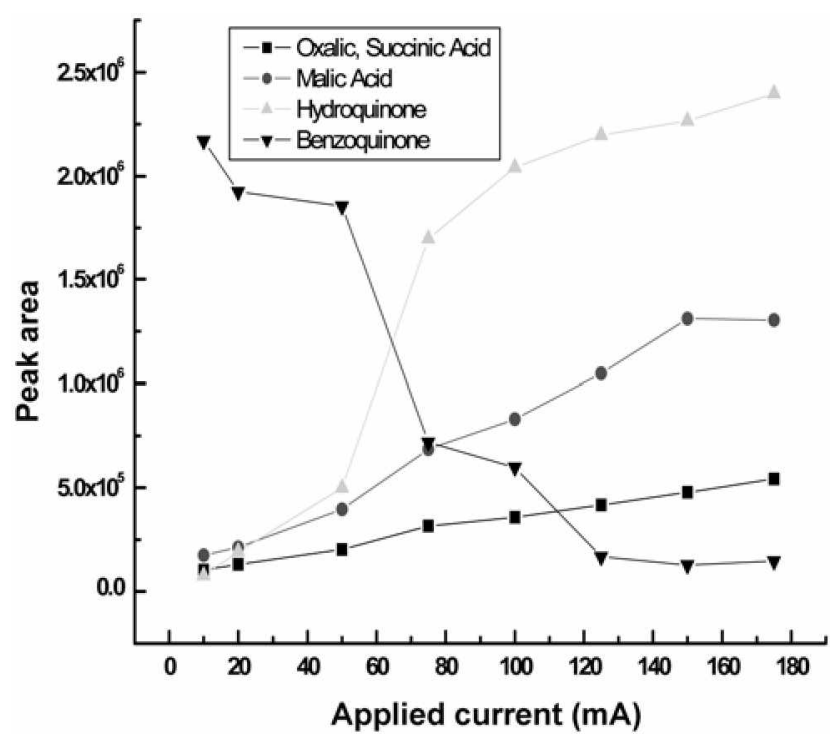

Figure 4. Product distribution as a function of the applied current for a controlled current electrolysis of $25 \mathrm{~mL}$ of a $1.0 \times 10^{-2} \mathrm{M}$ aqueous solution of $\mathrm{BQ}$ on the carbon fibers electrode for $\mathrm{I}$ hr. Electrolyte: $0.5 \mathrm{M} \mathrm{H}_{2} \mathrm{SO}_{+}$

current. The degradation products were identified as aliphatic acids. hydroquinone $\left(\mathrm{H}_{2} \mathrm{BQ}\right)$. and $\mathrm{BQ}$, Isimilar to Figure 3|. The peaks of small aliphatic acids increased as the applied current increased to $175 \mathrm{~mA}$ indicating that the increase in the peaks of aliphatic acids observed at the current range between 10 and $175 \mathrm{~mA}$ might be due to the formation of further oxidation products of $\mathrm{BQ}$. $\mathrm{H}_{2} \mathrm{BQ}$ formed by the reaction between $\mathrm{OH}$ produced in the strong acidic medium by the electrochemical oxidation of water. which was used as the solvent. and BQ present in solution. This reaction mechanism has been proposed by others for the electrochemical oxidation of aromatic compounds. ${ }^{27}$ The amount of $\mathrm{BQ}$ decreased rapidly with increasing applied current up to $75 \mathrm{~mA}$. For the electrolysis of BQ at an applied current higher than $75 \mathrm{~mA}$. the rate of degradation increased slowly. This might be explained by the conversion of $\mathrm{H}_{2} \mathrm{BQ}$ to aliphatic acids as the applied current was increased. The maleic acid content reached a maximum at an applied current of $150 \mathrm{~mA}$ and then decreased at currents higher than $150 \mathrm{~mA}$. which was probably due to the further oxidation of maleic acid to $\mathrm{CO}_{2}$ at the higher applied current. The concentration of $\mathrm{BQ}$ decreased rapidly as the applied current was increased up to $100 \mathrm{~mA}$, reaching a mininum value corresponding to about $50 \%$ of $\mathrm{BQ}$. in the current range higher than $125 \mathrm{~mA}$ for an hour period of electrolysis. The optimum applied current was $125 \mathrm{~mA}$ for an hour period of electrolysis.

Figure 5 shows the effect of degradation time on the amount of $\mathrm{BQ}$, which is converted to low molecular weight aliphatic acids and $\mathrm{CO}_{2}$. The $\%$ produced aliphatic acids, $\mathrm{H}_{2} \mathrm{BQ}$ and the unreacted $\mathrm{BQ}$ in a solution as a function of degradation time after at an applied current of $175 \mathrm{~mA}$ are shown in Figure 5. The amount of low molecular weight organic acids increased with increasing time. however, for 


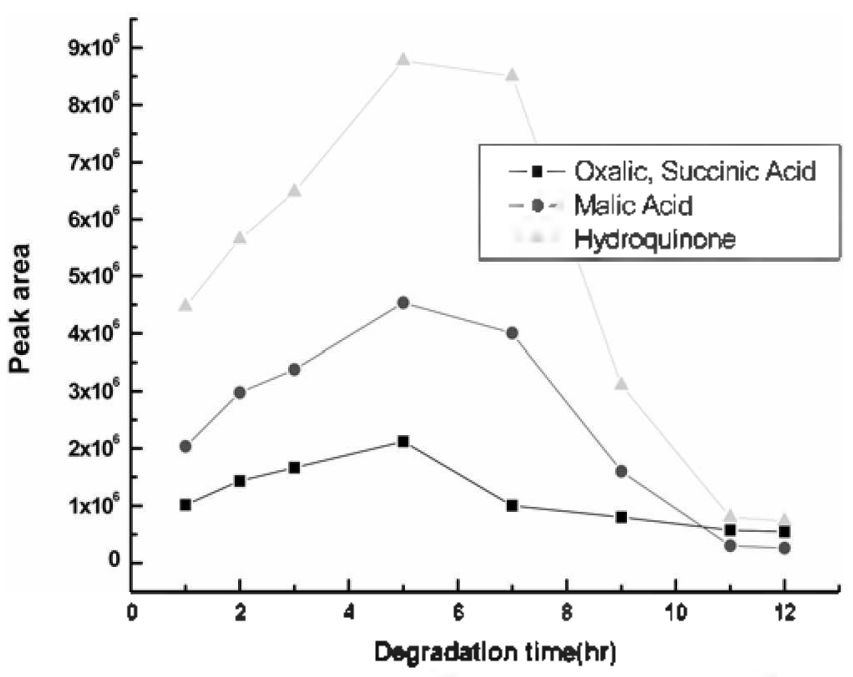

Figure 5. Product distribution as a function of reaction time for the controlled current electrolysis of $25 \mathrm{~mL}$ of a $1.0 \times 10^{-2} \mathrm{M}$ aqueous solution of $\mathrm{BQ}$ on the carbon fibers electrode. Reaction current : $175 \mathrm{~mA}$, Electrolvte: $0.5 \mathrm{M} \mathrm{H}_{2} \mathrm{SO}_{4}$

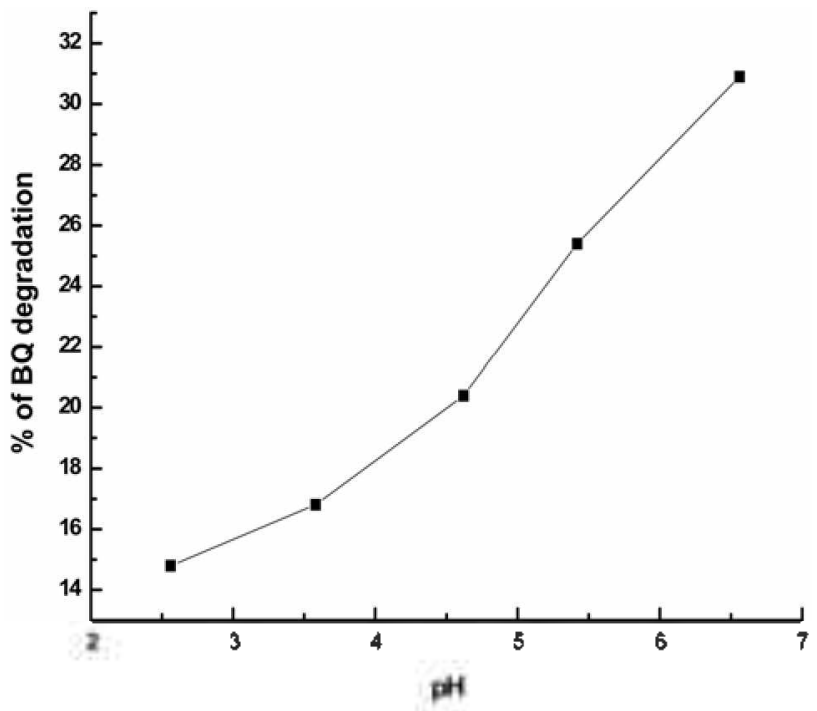

Figure 6. The percentage of $\mathrm{BQ}$ converted to $\mathrm{CO}_{2}$ as a function of $\mathrm{pH}$ for $25 \mathrm{~mL}$ of a $1.0 \times 10^{-2} \mathrm{M}$ aqueons solution of $\mathrm{BQ}$. Reaction time: $2 \mathrm{lu}$, Applied current: $175 \mathrm{~mA}$. Electrolyte: $0.5 \mathrm{M} \mathrm{H}_{2} \mathrm{SO}_{4}$.

an the electrolysis time greater than $5 \mathrm{hr}$, the anounts of organic acids decreased, due to the formation of $\mathrm{CO}_{3}$.

Effect of $\mathrm{pH}$ on the degradation of $\mathrm{BQ}$. To investigate the efficiency of the degradation of $\mathrm{BQ}$ as a function of the $\mathrm{pH}$ of the medium. the $\mathrm{pH}$ of the solution was varied from $\mathrm{pH} 2.56$ to 6.56 with an acetate buffer solution. Electrolyses were carried out at an applied current of $200 \mathrm{~mA}$ for $2 \mathrm{hr}$. when the complete oxidation of BQoccurs. Figure 6 shows the amount of $\mathrm{BQ}$ converted to $\mathrm{CO}_{2}$ at various $\mathrm{pHs}$. As shown in Figure 6, the complete oxidation of $\mathrm{BQ}$ is favored at high initial $\mathrm{pH}$ values. The following mechanism. as shown in equation (2) is consistent with these observations since each step results in the production of hydrogen ions and an increase in initial $\mathrm{pH}$ would improve the driving force for each step.
Table 1. Percentage of $\mathrm{BQ}$ degradation as a function of applied current for a $12 \mathrm{hr}$ period of electrolysis of $25 \mathrm{~mL}$ of a $1.0 \times 10^{-1} \mathrm{M}$ aqueous solution of $\mathrm{BQ}$. Amounts of $\mathrm{H}_{2} \mathrm{BQ}$ and aliphatic acids produced.

\begin{tabular}{|c|c|c|c|}
\hline \multirow[b]{2}{*}{ Current (mA) } & \multicolumn{2}{|c|}{ Products of degradation } & \multirow{2}{*}{$\begin{array}{c}\text { Degradation } \\
\text { of } \mathrm{BQ}(\%)\end{array}$} \\
\hline & $\begin{array}{c}\mathrm{H}_{2} \mathrm{BQ} \text { and } \\
\text { aliphatic acid (\%) }\end{array}$ & $\mathrm{CO}_{2}(\%)$ & \\
\hline 50 & 29.01 & 18.83 & 54.70 \\
\hline 75 & 23.64 & 22.34 & 55.43 \\
\hline 100 & 28.81 & 26.26 & 62.97 \\
\hline 150 & 40.89 & 35.39 & 85.61 \\
\hline 175 & 47.03 & 41.65 & 99.23 \\
\hline 200 & 49.10 & 42.45 & 99.62 \\
\hline
\end{tabular}

$$
\begin{aligned}
& \mathrm{C}_{6} \mathrm{H}_{4} \mathrm{O}_{2}+6 \mathrm{H}_{2} \mathrm{O} \rightarrow \mathrm{C}_{4} \mathrm{H}_{4} \mathrm{O}_{4}+12 \mathrm{H}^{-}+2 \mathrm{CO}_{2}+12 e^{-} \\
& \mathrm{C}_{4} \mathrm{H}_{4} \mathrm{O}_{4}+4 \mathrm{H}_{2} \mathrm{O} \rightarrow 12 \mathrm{H}^{-}+4 \mathrm{CO}_{2}+12 e^{-} \\
& 2 \mathrm{H}_{2} \mathrm{O} \rightarrow \mathrm{O}_{2}+4 \mathrm{H}^{-}+4 e^{-}
\end{aligned}
$$

The degradation of $\mathrm{BQ}$ to $\mathrm{CO}_{2}$. Table 1 summarizes the contents of products degraded as a function of applied current for 12 lurs oxidation of a $1.0 \times 10^{-2} \mathrm{M}$ aqueous solution of $\mathrm{BQ}$. The amounts of degradation products of $\mathrm{BQ}$ were determined from the ratio of the peak areas in the HPLC plot as shown in Figure 3. The results show that the complete oxidation of $\mathrm{BQ}$ to $\mathrm{CO}_{2}$ in an aqueous solution increased with higher the current density. At lower applied currents, the degradation products of $B Q$ were mainly $\mathrm{H}_{2} \mathrm{BQ}$. and aliphatic acids such as, oxalic acid and maleic acid. For $12 \mathrm{hrs}$ electrolysis of $\mathrm{BQ}$ at an applied current of $50 \mathrm{~mA}$. only $54.70 \%$ of the $\mathrm{BQ}$ was degraded to $\mathrm{H}_{2} \mathrm{BQ}$, aliphatic acids $(29.01 \%)$ and $\mathrm{CO}_{2}(18.83 \%)$. However. $99.62 \%$ of the $B Q$ was degraded to the $\mathrm{H}_{2} \mathrm{BQ}$, aliphatic acids $(49.10 \%)$ and $\mathrm{CO}_{2}(42.45 \%)$ at an applied current of $200 \mathrm{~mA}$. The degree of complete degradation was low at $50 \mathrm{~mA}$ reaction. however. the efficiency was rapidly increased at the applied

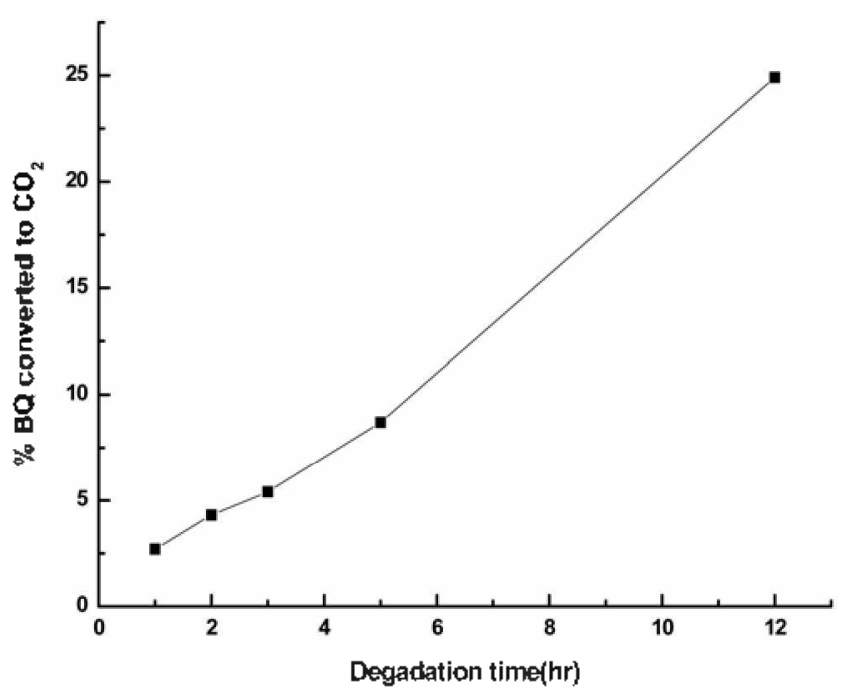

Figure 7. 'l he percentage of $\mathrm{BQ}$ converted to $\mathrm{CO}_{2}$ as the function of time for $25 \mathrm{~mL}$ of a $1.0 \times 10^{-2} \mathrm{M}$ aqueous solution of $\mathrm{BQ}$ on the carbon fibers electrode under constant current electrolysis. Applied current: $100 \mathrm{~mA}$, Electrolyte : $0.5 \mathrm{M} \mathrm{H}_{2} \mathrm{SO}_{4}$. 
current over $150 \mathrm{~mA}$ and the ratio of aliphatic acid to $\mathrm{CO}_{2}$ become constant. This means the complete decomposition of $\mathrm{BQ}$ needs longer reaction time.

Figure 7 shows the percentage of $\mathrm{BQ}$ converted completely to $\mathrm{CO}_{2}$ as a function of degradation time for a $1.0 \times 10^{-2} \mathrm{M} \mathrm{BQ}$ solution at $100 \mathrm{~mA}$. The efficiency of decomposition for the complete oxidation of $\mathrm{BQ}$ to $\mathrm{CO}_{2}$ was deternined by trapping the $\mathrm{CO}$ z produced with an excess amount of $\mathrm{Ba}(\mathrm{OH})_{2}$ solution as described in the experimental section. The residual $\mathrm{Ba}^{2-}$ ion in the solution was determined by ICP/ AES. The efficiency of degradation of $B Q$ as a function of the electrolysis time was calculated stoichiometrically using the following equation. ${ }^{3}$

$$
\begin{aligned}
& \mathrm{C}_{6} \mathrm{H}_{4} \mathrm{O}_{2}(a q) \rightarrow 6 \mathrm{CO}_{2}(\mathrm{~g})+2 \mathrm{H}_{2}(\mathrm{~g}) \\
& \mathrm{Ba}(\mathrm{OH})_{2}(a q, \operatorname{excess})+\mathrm{CO}_{2}(\mathrm{~g}) \rightarrow \\
& \mathrm{BaCO}_{3}(\mathrm{ppt})+\mathrm{H}_{2} \mathrm{O}+\mathrm{Ba}^{2+}(a q)+2 \mathrm{OH}^{-}(a q)
\end{aligned}
$$

As shown in Figure 7, the amount of $\mathrm{CO}$ : generated from the degradation of $\mathrm{BQ}$ increased with increasing electrolysis time and $26.0 \%$ of $\mathrm{BQ}$ was completely degraded to $\mathrm{CO}_{2}$ in 12 hrs at an applied current of $100 \mathrm{~mA}$. The degree of complete degradation would be increased as the applied current is increased. The complete degradation would be achieved as increasing the applied current and the reaction period.

\section{Conclusions}

The anodic degradation of $\mathrm{BQ}$ was carried out and experimental conditions for the degradation of $\mathrm{BQ}$ were optimized. With $25 \mathrm{~mL}$ of a $1.0 \times 10^{-2} \mathrm{M}$ aqueous solution of $B Q$. the efficiency increased with reaction time of up to 12 hrs. More than $99.0 \%$ of the $B Q$ to $H_{-} B Q$, aliphatic acids and $\mathrm{CO}_{2}$ at currents higher than $175 \mathrm{~mA}$ for a $12 \mathrm{hr}$ reaction. The degradation efficiency of $\mathrm{BQ}$ increased with an increase in the $\mathrm{pH}$ of the sample solution. The optimum efficiency was determined to be at a $\mathrm{pH}$ of 6.56 . The final product of the oxidation of $\mathrm{BQ}$ was $\mathrm{CO}_{2}$. However, $\mathrm{H}_{2} \mathrm{BQ}$ and aliphatic acids such as oxalic and maleic acid were produced as intermediates in the electroly'sis of $\mathrm{BQ}$. The optimized conditions for an electrochemical treatment of $25 \mathrm{~mL}$ of a $1.0 \times 10^{-2} \mathrm{M}$ aqueous solution of BQ were as follows: an applied current of $175 \mathrm{~mA}$. reaction time $12 \mathrm{hrs}$ in a neutral solution
Acknowledgement. This subject is supported by Ministry of Environment as "The Eco-tecluopia 21 project" and the Center for Integrated Molecular System (R11-2000-070070010 ).

\section{References}

1. Brillas, E: Sauleda. R.: Casado. J. J. Electrochem Soc. $1998,145$. 759.

2. Kirk. D. W.: Sharifian, H.: Foulkes. F. R. J. Appl. Electrochem. 1985. 15,285

3. Gattrell. M.: Kirk. D. W. Cam. J. Chem. Eng. 1990. 68.997.

4. Boye. B.: Dieng. M.: Brillas. E. Enwront. Sci. Technol. 2002. 36. 3030 .

5. Alberici, R. M.: Jardim. W. F. Hater Res. 1994. 28.1845

6. Koyama O.: Kamagata, Y; Nakamura, K. Water Res. 1994, 28. 895.

7. Esplugas. S.: Yue. P. L.: Perverz. M. I. Water Res. 1994. 28. 1323

8. Lee. S. H.: Oh. J. Y.: Park. Y. C. Bull. Korean Chent. Soc. 2006. $27(4) .489$.

9. Polcaro. A. M.: Palmsa. S. Ind. Eng. Chem Res. 1997, 36. 1791.

10. Juttner. K.: Galla. U.: Schmieder, H. Electrochim. Acta 2000, 45 2575 .

11. Stefan. M. I.: Bolton. T. R. Enwiron. Sci. Technol 1998. 32. 1588.

12. Boudent1e. T. L.: Cerclier. O. Water Res. 1994. 33.494

13. Druliolle. H.: Kokoh. K. B.: Hahn1. F.: Lamy. C.: Beden. B. J. Electroand. Chem. 1997, 426. 103.

14. Florou. A. B.: Prodromidis, M. I.; Karayannis, M. I.: TzouwaraKarayanni, S. M. Electroanalysis 1998. 10. 1261.

15. Tennakoon. C. L. K.: Bhardwaj. R. C.: Bockris. I. O. J. Appl. Electrochent. 1996. 26. 18

16. Comninellis. Ch.: Nerini. A. J. Appl. Electrochem. 1995. 25. 23

17. De Sucre. V. S.: Watkinsont. A. P. Can. J. Chent. Eng. 1981. 59. 52

18. Bock. C.: MacDougall. B. J. Electrochem. Soc 1999. 1+6, 2925.

19. Hofseth, C. S.; Chapman. T. W. J. Electrochem Soc. 1999. 146. 99.

20. Zhou. M.: Dai. Q.: Lei. L.: Ma. C.: Wang. D. Eminon. Sci Technol. 2005. 39. 363.

21. Vyssides, A.: Barampouti, E. M.: Mai. S. A. Enniron. Sci. Technol. 2004. 38,6125

22. Pulgarin, J. C. Adler. N.: Peringerr, P.: Comninellis. Ch. Water Res. 1994. 28.887.

23. Yoon. T. H.: Won1. M. S.: Shim. Y. B. Proceedings of the 2nd Cross Strats Sintpositum on Haterials, Enterg and Emiromtental Sciences 2000. 2-3 Nov.

24. Oyama. M: Okazaki, S. Anal. Chem 1998. 70.5079.

25. Shim. Y. B.; Park. S. M. J. Electronal. Chem. 1997. +25, 201.

26. Lian. H. Z.: Mao. L.: Ye. X. L.: Miao. J. J. Phamacentical and Bionedical Anahyis 1999.19.621.

27. Comninellis. Ch.: Pulgarin. C. J. Appl. Electrochen. 1993. 23. 108. 